\title{
S 状結腸間膜由来悪性末梢神経鞘腫の 1 例
}

滋賀医科大学外科学講座 ${ }^{12}$, 同 臨床看護学講座 ${ }^{2}$, 同 臨床検査医学講座 ${ }^{3}$

園 田寞 道 ${ }^{1)}$ 清 水智 治 ${ }^{1)}$ 太田 裕 之 ${ }^{1)}$

遠藤善 裕 ${ }^{2}$ 石田光 明 ${ }^{2)}$ 谷眞 至 ${ }^{1)}$

症例は67歳の女性で, 残尿感と下腹部腫瘤を主訴にかかりつけ医を受診した，腹部超 音波検查にて骨盤内腫瘤を認めたため，当科紹介受診となった，腹部造影 CTにて骨盤 内に径 $120 \mathrm{~mm}$ 大の辺縁平滑で内部は不均一に造影される $\mathrm{S}$ 状結腸間膜由来の腫瘍を認 め, 画像上脂肪肉腫と診断され，2011年 6 月に手術を施行した．開腹所見ではS 状結腸 間膜に結腸壁と連続する径 $15 \mathrm{~cm}$ 大の腫瘍を認めた。周囲臟器への浸潤は認めず，術式 はS 状結腸切除術とした，病理組織学的検査所見では, c-kit・desmin陰性の紡錘形細 胞の増生を認め, 一部に CD 34・S-100陽性細胞が観察され, 腸間膜由来の悪性神経䩗 腫と診断された，悪性神経鞘腫は神経鞘に原発する悪性腫瘍であり，主に頭頸部や四肢 の末䩗神経, 脊髄内に発生する. 腸間膜由来の悪性神経鞘腫は本邦では自験例を含めて 過去 5 例の報告しかなく非常にまれであるので報告する.

索引用語：悪性末梢神経鞘腫, 腸間膜

\section{はじめに}

悪性神経鞘腫瘍 (malignant peripheral nerve sheath tumor； 以下, MPNST と略記) は神経鞘に原発する 悪性腫瘍であり, 主に頭頸部や四肢の末鞘神経, 脊髄 内に発生する. また, 約半数が常染色体優性遺伝病で ある神経瀻維腫症I型（von Recklinghausen 病; 以下, VR病と略記）患者に生じるとされている．腸間膜由 来のMPNSTは，われわれが検索しえた限り本邦では 過去 4 例の報告しかなく非常にまれである ${ }^{1) \sim 4)}$. 今回, われわれは非VR病患者に発生したこの非常にまれな S 状結腸間膜由来MPNSTの 1 例を経験したので文献 的考察を加えて報告する.

\section{症例}

患者：67歳, 女性.

主訴 : 残尿感, 下腹部腫瘤.

既往歴 : 高血圧, 高脂血症.

家族歴：特記すべきことなし。

現病歴：上記主訴のもと, かかりつけ医を受診した. 腹部超音波検查において骨盤内腫㢚を認めたため, 精

2015年 4 月 28 日受付 2015 年 5 月 25 日採用

〈所属施設住所〉

₹520-2192 大津市瀬田月輪町
査加療目的に当院紹介受診となった.

身体所見：下腹部やや右寄りに弾性硬な腫瘤を触知 した，可動性は良好で圧痛は認めなかった。下肢浮腫 も認めなかった.

多発性のカフェ・オレ斑, 腋窩や鼠径部の雀卵斑様 色素斑, 多発性・散在性の皮膚神経線維腫は認めなか った。

血液・生化学検査所見 : 未梢血液, 生化学検査に特 記すべき異常所見は認めなかった。腫瘍マーカーは CEA 2.2ng/ml, CA19-9 31U/ml, CA125 34U/ml と 正常範囲内であった.

注腸造影検査所見：S 状結腸にくちばし状の狭窄部 位を認めた。また，狭窄部の腸管壁は比較的平滑で表 面の潰瘍や壁不整も明らかでなく, 粘膜面への浸潤を 疑わせる所見も乏しかった（Fig. 1).

腹部造影CT 所見：骨盤内に径 $120 \times 101 \times 84 \mathrm{~mm}$ 大 の辺縁平滑で内部は不均一に造影される $\mathrm{S}$ 状結腸間膜 由来の腫瘍を認めた（Fig. 2A）。冠状断において, 腫 瘍が $\mathrm{S}$ 状結腸動脈からの血流によって栄養されている ことが確認できた（Fig. 2B）。

腹部MRI所見：骨盤正中に巨大な分葉状腫瘤を認 め, $\mathrm{T} 1$ 強調画像で頭側に脂肪と思われる高信号を認 めた (Fig. 3A)。T2 強調画像では充実部は不均一な 


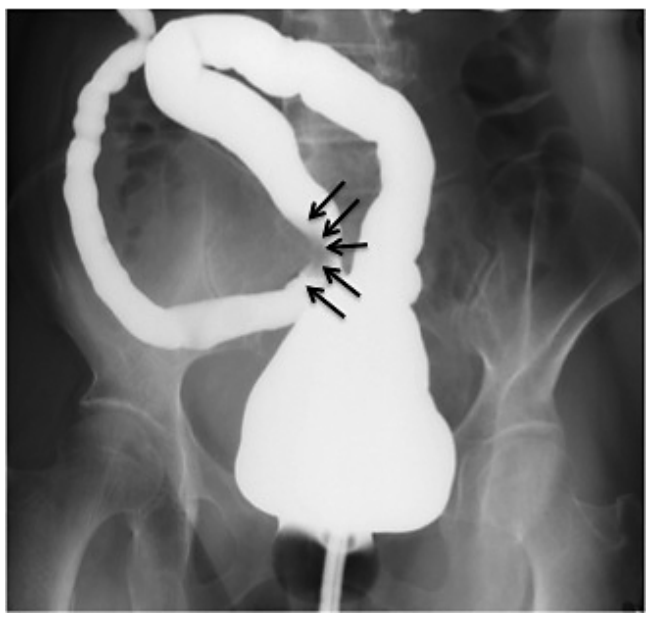

Fig. 1 Barium enema shows beak-like stenosis (arrow) in the sigmoid colon.
高信号主体の像を示した（Fig. 3B）.

以上の所見より, $\mathrm{S}$ 状結腸間膜由来の脂肪肉腫と診 断し, 手術（S状結腸切除術）を施行した.

手術所見 : S 状結腸から連続する腸間膜由来の16.5 $\times 13.0 \times 9.5 \mathrm{~cm}$ の弾性硬の腫瘍を認めた（Fig. 4). En blocに切除するため, 腫瘍と腸管との間は敢えて剥離 を試みず，S状結腸切除を行った。腫瘍は被膜損傷な く摘出した.

摘出標本：腫瘍は黄色調，分葉状で被膜を伴ってお り，肉眼的には腸管内腔に腫瘍は進展していなかった

(Fig. 5).

病理組織学的検査所見：浮腫性から膠原線維の増生 を伴う背景の中に好酸性細胞質を有する紡錘形細胞の 増生が認められた（Fig. 6A)，紡錘形細胞の核異型は

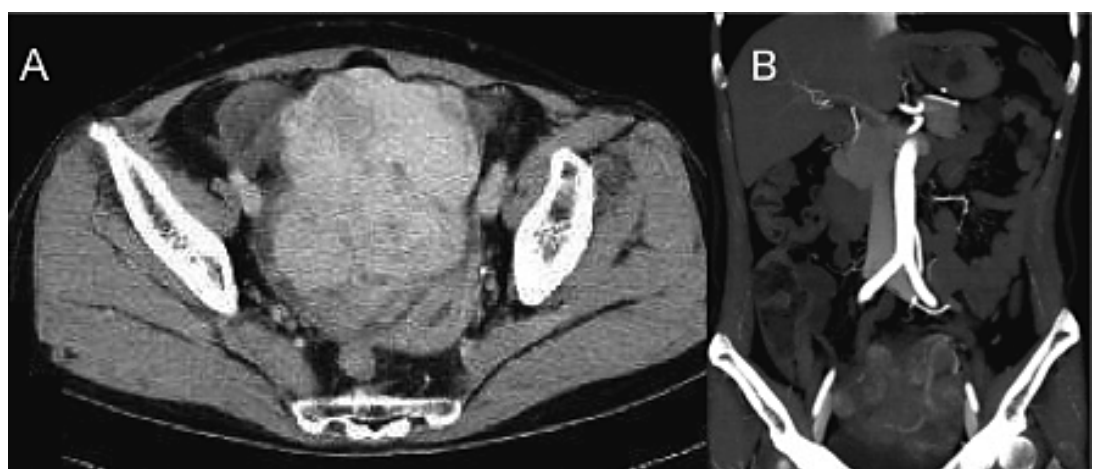

Fig. 2 Abdominal contrast-enhanced CT demonstrates a tumor with smooth surface in the pelvis. The tumor is $120 \mathrm{~mm}$ in diameter, with heterogeneous enhancement (A). On coronal view, the tumor is fed by the sigmoid colon artery (B).

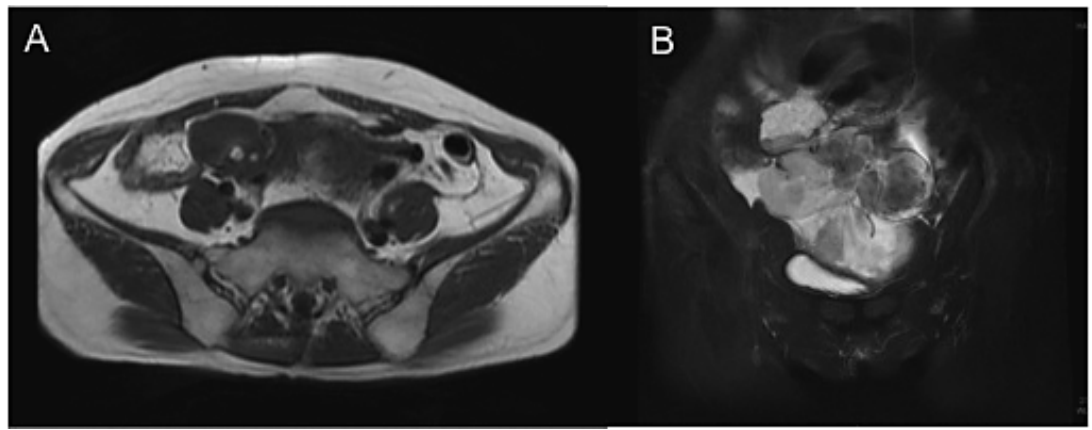

Fig. 3 Magnetic resonance imaging (MRI) shows a huge lobular mass in the pelvis. T1 -weighted MRI shows a high-intensity area on the upper side of the tumor (A), and T2-weighted MRI shows heterogeneous high intensity in the solid tumor (B). 


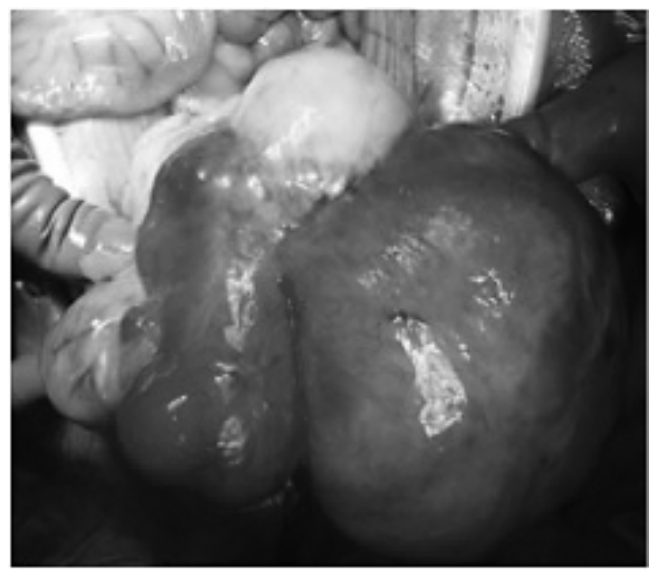

Fig. 4 Surgical findings. The tumor is $16.5 \mathrm{~cm}$ in diameter and located adjacent to the sigmoid colon.

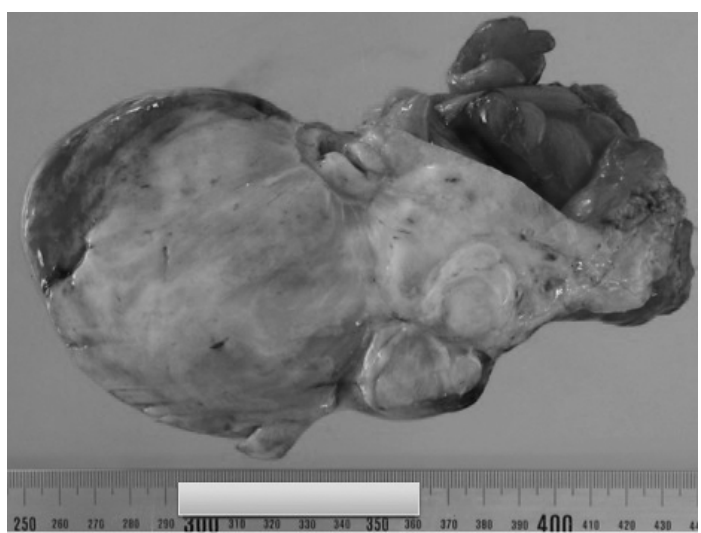

Fig. 5 The tumor is lobulated and encapsulated.
強く，核分裂像も認められた。核分裂数は高倍率50視 野に11個で, Ki-67 labelling indexは13.5\%であった. 病変は大腸壁（粘膜下層）への進展を認めた。腫瘍細 胞はS-100陽性 (Fig. 6B), CD34は一部にfocalに陽性, c-kit・desmin・ $\beta$-catenin は㓌性であった。

また，腫瘍組織のc-kit遺伝子変異解析を行ったと ころ, exon $9 \cdot$ exon 11 とも変異を認めなかった.

以上より, S 状結腸間膜由来 MPNST と診断した.

術後経過：術後合併症を認めず，退院となった。術 後補助化学療法の有効性に関するエビデンスがなかっ たため, 術後補助化学療法を行わず経過観察を行った. 術後 1 年の腹部造影 CT で，回腸腸間膜と腹壁に平衡 相で濃染される径 $15 \mathrm{~mm}$ 大の腫瘤を認め (Fig. 7A, B), MPNST 再発と診断し, 回腸部分切除, 腹壁腫 瘍切除を行った，術中，腹腔内を検索したが，他に再 発腫瘤は認めなかった.さらに半年後の腹部造影 CT で，空腸間膜に再発時と同様の径 $7 \mathrm{~cm}$ 大の腫瘤と同 腫瘤が原因となる腸閉塞を認めた。 MPNST再々発に よる腸閉塞と診断し, 空腸部分切除を行った. 再発, 再々発時の病理組織学的・免疫組織化学的所見は初回 手術と同様であった。 また，再々発時の術中小腸漿膜 面に $2-3 \mathrm{~mm}$ 大の小結節を多数認めたため, 初回手 術時の際に切除標本を用いて予め行っていたCollagen-gel droplet drug sensitivity test (以下CD-DST と略記）による抗癌剤感受性試験の結果（Fig. 8）と 過去に報告されている再発MPNSTに対する化学療法 の奏効例5)を参考にエトポシド $\left(100 \mathrm{mg} / \mathrm{m}^{2}\right.$, day $\left.1-3\right)$ +カルボプラチン（AUC：5, day1）による化学療
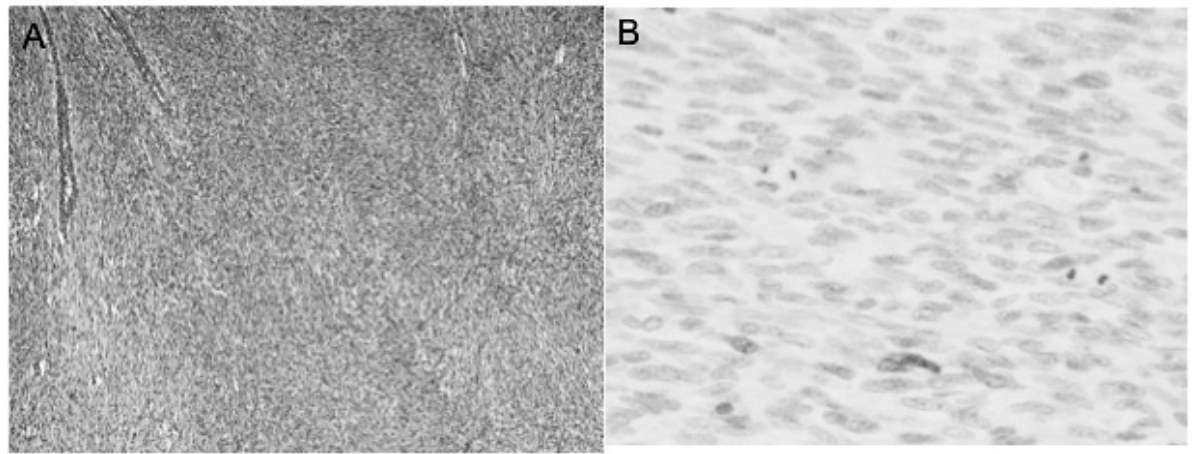

Fig. 6 Pathological studies of the resected specimen demonstrate spindle cell hypertrophy

(A). On immunohistochemical examination, these spindle cells are positive for S-100 protein (B). 


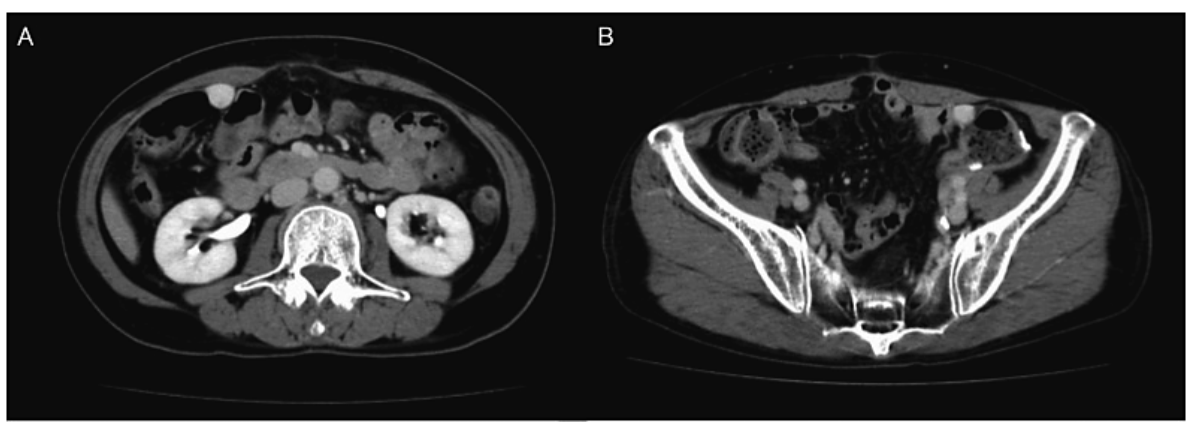

Fig. 7 Abdominal contrast-enhanced $\mathrm{CT}$ demonstrates tumors with smooth surfaces next to the peritoneum (A) and attached to the ileum (B). These tumors are both $15 \mathrm{~mm}$ in diameter, and well-enhanced in the equilibrium phase.

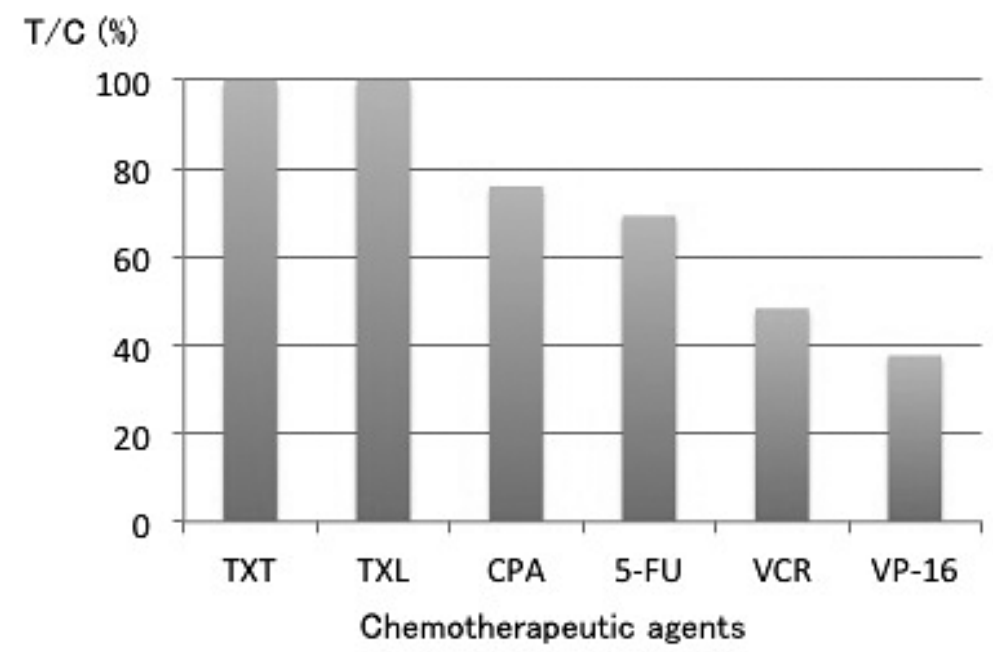

Fig. 8 Results of collagen gel droplet-embedded culture drug sensitivity test (CD-DST) of a recurrent tumor. The treated/control $(\mathrm{T} / \mathrm{C})$ ratio was used to index chemosensitivity. $\mathrm{T} / \mathrm{C}$ ratio was determined based on the ratio of the total volume of a tumor colony either in contact with $(\mathrm{T})$ or not in contact with (C) the drug. Tumor cells appeared to be sensitive to VP-16 and VCR.

法を行ったが，奏効せず，原発巣手術術後 2 年 2 力月 で腹腔内多発再発により死亡した。

\section{考察}

MPNST は全悪性軟部腫瘍の 5-10\%を占める末梢 神経鞘原発悪性腫瘍であり，主に頭頸部や四肢の末鞘 神経, 脊髄内に発生する。中でも腸間膜原発MPNST は非常にまれであり，1977年から2014年 3 月までの医 中誌Web Ver. 5 にて「腸間膜」と「MPNST」をキ ーワードとして検索（会議録を除く）した結果，これ
までの本邦での報告は自験例を含め 5 例のみであった （Table 1). 欧文での症例報告も，1950年から2014年 3 月までのPubMedにて「MPNST AND mesentery」 をキーワードとしてした結果，4例6) -9) しかなく非常 にまれな病態であると考えられる。また，MPNSTの 症例の約半数はVR病の患者に併発するとされ ${ }^{10)}$, 腸 間膜原発MPNST の本邦での報告例でも 5 例中 4 例に 合併が認められているが，本症例では合併を認めなか った，本疾患は腸管外に首座があるため, 特有の臨床 


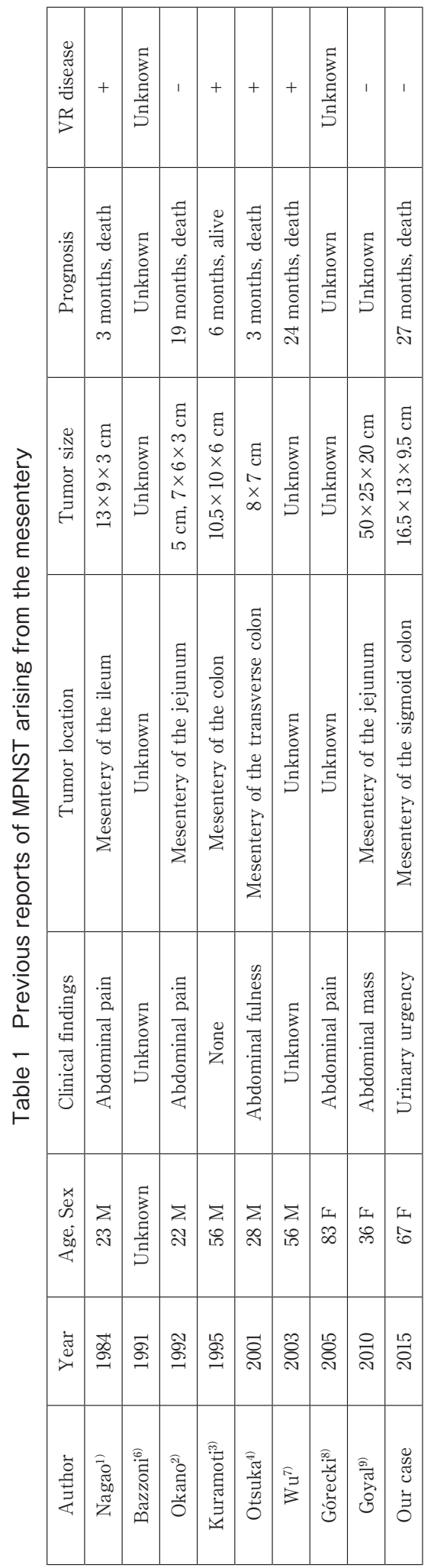

症状にそしく，そのほとんどが巨大化してから発見さ れる．画像診断においてはMRIが神経原性腫瘍かど うかの鑑別には有用であるとされるが，良悪性の鑑別 は困難であると報告されている11)。また，CTも神経 線維腫と MPNST 鑑別する特異的な所見はなく, 周 囲臟器への進展や他臟器転移の有無の評価に用いられ るべき検査であるとされている10). 本症例においても 術前診断は不能であった，過去の報告例でも術前診断 できた症例はなく, 術前診断の限界が窺える.

病理組織学的検查所見においては, 組織学的に紡鍾 形細胞の増生と, 免疫組織化学染色においてS-100蛋 白やNSEが陽性であり, その他, 免疫染色で他疾患 の否定ができればその診断がつくと考えられている. MPNST との組織学的な鑑別疾患には, 滑膜肉腫・平 滑筋肉腫・皮膚線維肉腫が挙げられるが，本例におい ては $\beta$-catenin・desminによる免疫染色と発生母地 からこれらは否定的であり, 腫瘍の浸潤性増生, 核異 型や分裂像が認められたため悪性と判断した. 治療は, 切除断端陰性を確保した腫瘍の完全切除が最も有効な 治療とされている。しかし，再発率は高く，36-54\% に局所再発を認め, $65 \%$ 症例に肺・骨といった遠隔 転移を認め, 5 年生存率は $34-39 \%$ とされている ${ }^{12)}$. 術後補助化学療法や放射線療法の効果が確立されてい ないため, 初回手術後は術後補助化学療法を行わず, 経過観察した。しかし，短期間で再発をきたし，また 3 回目手術時には腸管に微小な結節病変が残存したた め, 術後補助化学療法を行うこととした。当科ではこ れまで, 大腸癌に対してCD-DSTによる抗癌剤感受 性試験を行い, 同法に基づいた術後補助化学療法の有 用性を報告してきており ${ }^{13)}$, 本症例でも, 初回手術時 に摘出標本を用いて，CD-DST法を行った，そこで， 本症例での感受性試験で高感受性と判定されたエトポ シドを用いた再発MPNST に対する化学療法の奏効例 が報告されている5)ことや，軟部腫瘍に対する $\mathrm{CD}^{5}$ DST法に基づいた化学療法の奏効例が報告されてい

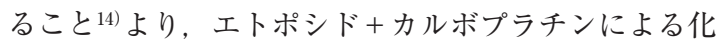
学療法を半年間行ったが, 全く奏効せず, 化学療法終 了後に行った腹部 CT 検査にて腹腔内多発再発を認 め, 手術不能と判断した. そして, 再発確認後 2 力月, 初発手術から 2 年 2 力月で原病死した。本症例では CD-DSTによる抗癌剤感受性試験に基づいた化学療 法は奏効しなかったが, 本症例の結果だけでMPNST に対するCD-DST の有効性について判断することは 時期尚早であり，今後さらに症例を集積して検討する 
必要があるであろう。

\section{結語}

極めてまれな腸間膜由来の悪性末梢神経鞘腫の 1 例 を経験した

\section{文献}

1）長尾俊彦, 重信雅春, 寺本 滋他 : 腸間膜神経線 維腫およびその悪性化を伴ったRecklinghausen 病の 1 例. 癌の臨 $1984 ; 30: 968-974$

2) 岡野 亨, 津田知宏, 酒井昌博他: 小腸腸間膜お よび空腸に発生した悪性神経鞘腫の 1 例. 腹部救 急診療の進歩 $1992 ; 12: 445-447$

3）倉持佳奈子, 成高義彦, 小川健治他：von Recklinghausen病に合併した結腸間膜悪性神経鞘腫の 1 例. 外科 $1995 ; 57: 1360-1364$

4）大塚由一郎, 金子弘真, 石井貴士他：von Recklinghausen病に伴う腸間膜原発悪性末梢神経鞘腫 の 1 例。 日臨外会誌 $2001 ； 62 ： 1534-1537$

5) Kinebuchi $Y$, Noguchi W, Igawa $Y$, et al : Recurrent retroperitoneal malignant nerve sheath tumor associated with neurofibromatosis type 1 responding to carboplatin and etoposide combined chemotherapy. Int J Clin Oncol 2005 ; 10 : $353-356$

6) Bazzoni C, Ongari M, Crespi A, et al : Malignant Schwannoma of the mesentery. Presentation of a clinical case and clinical and histopathological considerations. Minerva Chir 1991 ; 46 : 413 416

7) WU CC, Peng HL, Su CT, et al : Mesenteric and retroperitoneal malignant peripheral nerve sheath tumors in a patient with neurofibromato- sis type 1 . Chin J Radiol $2003 ; 28$ : $193-198$

8) Górecki T, Ostrowska M, Kaszuba B, et al : Malignant peripheral nerve sheath tumour originating in nerofibroma of the mesentery. Case report. Pol J Pathol $2005 ; 56: 145-147$

9) Goyal V, Thomas S, Pathania O P, et al : Malignant nerve sheath tumor of the mesentery. Indian J Cancer 2010 ; 47 : $233-234$

10) Enzinger FM, Weiss SW : Malignant tumors of peripheral nerves. Soft Tissue Tumors, CV Mosby, St. Louis, 1988, p781 - 800

11) Grobmyer SR, Reith JD, Shahlaee A, et al : Malignant Peripheral Nerve Sheath Tumor : molecular pathogenesis and current management considerations. J Surg Oncol 2008 ; 97 : $340-349$

12）長谷川匡, 下田忠和：悪性末梢神経鞘腫瘍 (MPNST) の形態的特徵と鑑別診断. 病理と臨 $1999 ; 17: 959-963$

13) Mekata E, Sonoda H, Shimizu T, et al : Clinical predictive value of in vitro anticancer drug sensitivity test for the therapeutic effect of adjuvant chemotherapy in patients with stage II-III colorectal cancer. Mol Clin Oncol 2013 : $1: 763$ $-767$

14) Yamamoto $Y$, Hiasa $Y$, Hirooka M, et al : Complete response of a patient with advanced primary splenic histiocytic sarcoma by treatment with chemotherapeutic drugs selected using the collagen gel droplet-embedded culture drug sensitivity test. Intern Med $2012 ; 51$ : 2893 2897

\title{
MALIGNANT PERIPHERAL NERVE SHEATH TUMOR ARISING FROM THE MESENTERY OF THE SIGMOID COLON-REPORT OF A CASE-
}

\author{
Hiromichi SONODA ${ }^{1)}$, Tomoharu SHIMIZU ${ }^{1)}$, Hiroyuki OHTA ${ }^{1)}$, Yoshihiro ENDO ${ }^{2)}$, \\ Mitsuaki ISHIDA ${ }^{3)}$ and Masaji TANI ${ }^{1)}$ \\ Department of Surgery ${ }^{1}$, Department of Clinical Nursing ${ }^{2)}$, Department of Clinical Laboratory Medicine ${ }^{3)}$, \\ Shiga University of Medical Science
}

A 67-year-old woman was admitted with urinary urgency and a lower abdominal mass. Abdominal CT showed a tumor $120 \mathrm{~mm}$ in diameter that was vascularized by the sigmoid colon artery in the abdominal cavity. The tumor was diagnosed as liposarcoma. We performed sigmoidectomy in June 2011. Intraoperatively, the tumor was about $15 \mathrm{~cm}$ in diameter and located at the sigmoid mesocolon adjacent to the sigmoid colon. Histological examination confirmed the diagnosis of malignant peripheral nerve sheath tumor (MPNST) originating from the sigmoid mesocolon. She received two operations for tumor recurrence, and adjuvant chemotherapy after the third operation, but died of abdominal dissemination 26 months after the initial operation.

Key words : malignant peripheral nerve sheath tumor, mesentery 